\title{
Mortality experience of 161 employees exposed to ethylene dibromide in two production units
}

\author{
M G OTT, H C SCHARNWEBER, AND R R LANGNER \\ From the Epidemiology Department, H\&ES, Dow Chemical USA, Midland, Michigan, USA
}

\begin{abstract}
Animal studies have indicated the carcinogenic potential of ethylene dibromide (EDB). Examination of the mortality experience of employees exposed to EDB in two production units operated from 1942 to 1969 and from the mid-1920s to 1976, respectively, showed that in the first unit two deaths from malignant neoplasms were observed against 3.6 expected (based on US white male mortality), and in the second unit, where there was potential exposure to various organic bromide products, five deaths from malignant neoplasms $(2 \cdot 2$ expected) were observed. Findings of this investigation neither rule out nor establish EDB to be a human carcinogen. Far fewer malignant neoplasms, however, have been observed than might have been expected from a direct extrapolation of data obtained from experiments on animals.
\end{abstract}

Concern regarding the carcinogenic potential of ethylene dibromide (EDB) was raised based on the results of animal studies conducted by Olson et al. ${ }^{1}$ Of 50 rats exposed at one half the maximum tolerated dose, $40 \mathrm{mg} / \mathrm{kg} /$ day administered by intragastric tube, 49 developed squamous-cell carcinomas of the stomach. The first tumour was observed as early as 12 weeks after initial exposure. In a more recent study increased tumour incidences were reported in rats exposed to 20 parts per million (ppm) EDB by inhalation, initially in a group of rats treated with $0.05 \%$ disulfiram in the diet, ${ }^{2}$ and thereafter in the group of rats on a control diet. ${ }^{3}$

Previous inhalation studies ${ }^{4}$ had indicated that rats exposed for up to six months to concentrations of $50 \mathrm{ppm}$ EDB showed evidence of injury to the lungs, liver, kidney, and spleen. No tumours were observed in this series of six-month studies that included rabbits, monkeys, and guinea pigs, as well as rats. Studies were also conducted at $25 \mathrm{ppm}$. The authors concluded that "rabbits and monkeys and probably rats and guinea pigs can tolerate without adverse effects daily repeated seven-hour exposures to a vapour concentration of $25 \mathrm{ppm}$ of ethylene dibromide."

Bondi and Alumot ${ }^{5}$ found that one of two bull calves fed EDB at $10 \mathrm{mg} / \mathrm{kg} /$ day from the third day after birth showed signs of pneumonia, lack of co-ordination, and inability to stand at 5 weeks.

Received 29 August 1979

Accepted 2 October 1979
Necropsy showed severe pneumonia and a fatty infiltration of liver and kidneys in one calf.

The present survey was undertaken to investigate the mortality experience of employees occupationally exposed to EDB in two manufacturing plants. The emphasis of the study was on cancer mortality and mortality due to respiratory disease.

\section{Environmental considerations}

The employees included in this investigation had worked either in an EDB manufacturing unit located in Michigan or in a second unit located in Texas. Since both of these operations have been discontinued (the Texas plant closed in 1969 and the Michigan plant in 1976), environmental assessments were based on existing records and discussions with employees formerly associated with the plants. Considerable differences existed between the two production units both from environmental and organisational standpoints.

The Texas plant, unit 1, was operated from 1942 to 1969 by a company that was a partially owned, but independently managed, subsidiary of The Dow Chemical Company. The process consisted of reactor and distillation operations, which were housed within the same building. Quantitative data were not available from which to calculate eight-hour time-weighted-average (TWA) exposure concentrations of EDB at this installation. It is known that during the early 1960 s batch reactors were replaced by continuous reactors and this change would have 
led to considerably reduced exposure concentrations. The final product was loaded directly into tank cars. Since no other organic bromide products were manufactured at the location, exposure was primarily to EDB, bromine, ethylene, sulphur dioxide, and chlorine. The job classifications included in the study for this plant were reactor operator, still operator, foreman, and lead burner. The lead burners were included in the study since individuals with this classification could have spent up to $90 \%$ of their time in the EDB production area repairing glass and lead lines.

The EDB process in Michigan, unit 2, was started up in the mid-1920s. Although EDB was produced continuously until 1976, the process underwent numerous changes and had been assigned to several different production departments during its 50-year history. Manufacture of EDB began by reacting ethylene and bromine to form EDB. Over the years individuals who worked in this operation were potentially exposed to EDB, bromine, ethylene, hydrogen, iodine, ammonia, silica, copper acetate, nickel acetate, and vinyl bromide. The crude product was transferred to another building for distillation and drumming. The distillation operation was located in a production area where several other organic halogen compounds were used or were manufactured on a batch basis. At various times in the past still operators were directly exposed to trimethylene chlorobromide, propylene chlorobromide, ethyl bromoacetate, isobutyl bromide, acetylene tetrabromide, and were indirectly exposed to allyl chloride, benzene, bromochloromethane, carbon tetrachloride, chloroform, ethyl bromide, hydrogen bromide, methylene chloride, methylene dibromide, tert-bromobutyl phenol, tert-butyl phenol, and vinyl bromide. The operating crew included a reactor operator who worked in the reaction end of the process and a still operator who worked in the finishing end. Exposure to EDB has been reasonably well documented for these jobs. Other jobs in the production departments under investigation could have led to occasional exposure to EDB, but only individuals who worked as reactor or still operators were routinely exposed and included in the study population.

Industrial hygiene estimates of EDB exposure concentrations for the reactor and still operators were based on area sampling in 1950, 1952, and 1971-2, and based on area and personnel sampling in 1975 as presented in table 1 . In 195018 breathing zone samples ranged between 1.0 and $7.4 \mathrm{ppm}$ for the reactor operator, and between 2.2 and $10.6 \mathrm{ppm}$ for the still operator. In 1952 samples between the stills ranged from 19 to $24 \mathrm{ppm}$, and from 25 to 31 ppm on warm days. Breathing zone samples while filling drums of EDB ranged up to $13.4 \mathrm{ppm}$ and, after a spill, up to $71 \mathrm{ppm}$. Extensive monitoring was conducted during 1971 and 1972 using a continuous monitoring Beckman 12C infrared spectrophotometer; TWA concentrations of EDB for an eighthour day were $2.9 \mathrm{ppm}$ for the reactor operator and from 3.5 to $4.0 \mathrm{ppm}$ for the still operator. In 1975 area and personnel monitoring was conducted in the reaction end of the process; all TWA averages found for EDB were at $5 \mathrm{ppm}$ or below. Occasional excursions to concentrations of EDB above $75 \mathrm{ppm}$ are suspected, based on symptomatology. Past records indicate that industrial hygienists reported sensing a strong odour and respiratory irritation at about 75 ppm EDB. Gastrointestinal discomfort and vomiting may also be induced by acute exposure. Discussions with individuals familiar with the process indicate that symptoms compatible with exposures above $75 \mathrm{ppm}$ did occur. Between 1954 and 1970, three episodes of acute exposure with

Table 1 Summary of industrial hygiene measurements for EDB, unit 2, 1949-75

\begin{tabular}{|c|c|c|c|c|}
\hline Survey period & Job category & Estimated TWA (ppm) & Range of samples (ppm) & Qualifications \\
\hline 1949 (18 samples) & $\begin{array}{l}\text { Reactor operator } \\
\text { Still operator }\end{array}$ & & $\begin{array}{l}1-7 \cdot 4 \\
2 \cdot 2-10 \cdot 6\end{array}$ & $\begin{array}{l}\text { Breathing zone } \\
\text { Breathing zone }\end{array}$ \\
\hline 1952 (15 samples) & Still operator & & $\begin{array}{l}19-24 \\
25-31 \\
<13 \cdot 4 \\
<71\end{array}$ & $\begin{array}{l}\text { Between stills } \\
\text { Between stills (warm days) } \\
\text { Filling drums of EDB } \\
\text { After a spill while filling } \\
\text { drums }\end{array}$ \\
\hline 1971-2 (continuous) & $\begin{array}{l}\text { Reactor operator } \\
\text { Still operator }\end{array}$ & $\begin{array}{l}2 \cdot 9 \\
4 \cdot 0 \\
3 \cdot 5\end{array}$ & $\begin{array}{l}0 \cdot 4-38 \\
0-110 \\
0-23\end{array}$ & (Before shed fixed) \\
\hline $\begin{array}{r}1975 \text { (22 samples) } \\
\text { (2 samples) }\end{array}$ & Reactor operator & $\begin{array}{l}5 \cdot 0 \\
0 \cdot 8,1 \cdot 1\end{array}$ & $1 \cdot 8-96$ & $\begin{array}{l}\text { Breathing zone } \\
\text { Personnel monitoring }\end{array}$ \\
\hline
\end{tabular}

TWA $=$ Time-weighted-average exposure. 
Table 2 Summary of serum bromide concentrations measured as $\mathrm{mg} / 100 \mathrm{ml}$ among still and reactor operators of unit 2 by year*

\begin{tabular}{|c|c|c|c|c|}
\hline \multirow[t]{2}{*}{ Year } & \multicolumn{2}{|c|}{ Reoctor operator } & \multicolumn{2}{|c|}{ Still operator } \\
\hline & No of men & $M \pm I S D$ & No of men & $M \pm 1 S D$ \\
\hline $\begin{array}{l}1957 \\
1959 \\
1961 \\
1966 \\
1967-8 \\
1970\end{array}$ & $\begin{array}{l}4 \\
6 \\
4 \\
4 \\
3 \\
3\end{array}$ & $\begin{array}{l}7 \cdot 3 \pm 6 \cdot 6 \\
8 \cdot 7 \pm 3 \cdot 8 \\
8 \cdot 0 \pm 4 \cdot 3 \\
2 \cdot 0 \pm 0 \cdot 8 \\
2 \cdot 3 \pm 1 \cdot 2 \\
4 \cdot 0 \pm 2 \cdot 0\end{array}$ & $\begin{array}{l}5 \\
5 \\
2 \\
2 \\
2 \\
2\end{array}$ & $\begin{array}{r}\mathbf{7 . 7} \pm \mathbf{4 . 0} \\
7.0 \pm \mathbf{4 . 7} \\
9.0 \pm 4.2 \\
2.0 \pm 0.0 \\
6.0 \pm \mathbf{4 . 2} \\
13.0 \pm 0.0\end{array}$ \\
\hline
\end{tabular}

*Depending on medications, diet, and possibly other factors, background serum bromide concentrations range up to $5 \mathrm{mg} / 100 \mathrm{ml}$.

respiratory or gastrointestinal involvement were reported to the medical department by individuals in the study.

Biological monitoring of blood bromide concentrations had been conducted since 1957 in organic bromide production areas. Table 2 summarises the blood bromides determined for reactor and still operators between 1957 and 1970. The blood bromide concentrations ranged from $1 \mathrm{mg} / 100 \mathrm{ml}$ to $17 \mathrm{mg} / 100 \mathrm{ml}$ over the period, with a mean of $6.5 \mathrm{mg} / 100 \mathrm{ml}$. These findings are not specific for EDB in the presence of other process chemicals containing bromine. In addition, non-prescription medications, bromides in drinking water, and certain foods may raise blood bromide concentrations.

\section{Method of analysis}

Employees from both units were identified by reviewing annual census lists and selecting all reactor and still operators from unit 2, and lead burners, reactor and still operators, and foremen from unit 1 . Of the men in unit 1, 19 had worked as lead burners. In unit 2 individuals who left the company before 1940 were not included in the study, partly because of the difficulty of conducting social security follow-

Table 3 Employment and vital status of 161 ethylene dibromide employees as of 1 January 1976

\begin{tabular}{llll} 
& \multicolumn{3}{l}{ No of men } \\
\cline { 2 - 4 } & Unit I & Unit 2 & $\begin{array}{l}\text { Unit 2 } \\
\text { less arsenicals } \\
\text { emplovees }\end{array}$ \\
& & & 57 \\
\hline Total population & 99 & 62 & 57 \\
$\quad$ Still working & 17 & 31 & 29 \\
Retired & 17 & 9 & 9 \\
Dead (company records) & 13 & 14 & 11 \\
Left company & & & \\
Social security cheques & 43 & 4 & 4 \\
$\quad$ indicate alive & 8 & 4 & 4 \\
$\quad$ Dead & 1 & 0 & 0 \\
Not traced & & & \\
\hline
\end{tabular}

up. The total cohort population consisted of 161 employees from both units. Since the sampling frame was based on January census lists, some individuals with exposures of less than 12 months would not have been identified. The employment and vital status of the 161 EDB employees as of 1 January 1976 are shown in table 3. Follow-up of employees who left the company has been conducted primarily through the social security administration. This method of follow-up may not provide $100 \%$ identification of decedents among former employees. Expected deaths were calculated from observed mortality rates for US white males, by five-year age groups, for the years 1942, 1947, 1952, 1957, 1962, 1967 , and 1971. Person-years lived by the cohort population were multiplied by the appropriate mortality rates and accumulated to yield the expected number of deaths.

Five individuals exposed to arsenicals, in addition to EDB, were treated separately in the analysis because of prior indications based on work by Ott et $a l^{6}$ that employees who worked in an arsenicals formulation plant at this location were at increased risk of developing respiratory malignancies.

Table 4 Duration of exposure by year of first exposure for each unit

\begin{tabular}{llrlll}
\hline $\begin{array}{l}\text { Unit and year of } \\
\text { first exposure }\end{array}$ & \multicolumn{5}{l}{ Duration of exposure $(y r)$} \\
\cline { 2 - 6 } & $<1$ & $1-5$ & $6-10$ & $11-15$ & $\geqslant 16$ \\
\hline Unit 1 & 14 & 29 & 10 & 4 & 14 \\
$1940-9$ & 10 & 14 & - & 1 & 1 \\
$1950-9$ & - & 2 & - & - & - \\
$\geqslant 1960$ & 24 & 45 & 10 & 5 & 15 \\
Total & & & & & \\
Unit 2 & - & -6 & - & 1 & - \\
$1925-9$ & - & 6 & 3 & 2 & 1 \\
$1930-9$ & 1 & 11 & 1 & - & 1 \\
$1940-9$ & 2 & 7 & 5 & - & - \\
$1950-9$ & 4 & 15 & 2 & - & - \\
$\geqslant 1960$ & 7 & 39 & 11 & 3 & 2 \\
Total & & & & &
\end{tabular}


Table 5 Observed and expected ${ }^{*}$ deaths for selected causes by unit, 1940-75

\begin{tabular}{|c|c|c|c|c|}
\hline & \multicolumn{2}{|l|}{ Unit 1} & \multicolumn{2}{|c|}{ Unit 2 less arsenicals employees } \\
\hline & Observed & Expected & Observed & Expected \\
\hline All causes & 21 & $19 \cdot 5$ & 15 & $13 \cdot 0$ \\
\hline Malignant neoplasms (total) & 2 & $3 \cdot 6$ & 5 & $2 \cdot 2$ \\
\hline Respiratory system & 1 & $1 \cdot 2$ & 0 & $0 \cdot 6$ \\
\hline Digestive system & 1 & 1.0 & 2 & $0 \cdot 7$ \\
\hline All other sites & 0 & $1 \cdot 4$ & 3 & 0.9 \\
\hline Diseases of cardiovascular system & 11 & $9 \cdot 1$ & 6 & $7 \cdot 0$ \\
\hline Emphysema, chronic bronchitis, and asthma & 0 & $0 \cdot 4$ & 1 & $0 \cdot 2$ \\
\hline Influenza, pneumonia & 0 & 0.4 & 2 & 0.3 \\
\hline All external causes & 3 & $2 \cdot 8$ & 0 & $1 \cdot 3$ \\
\hline All other causes & 2 & $3 \cdot 2$ & 1 & $2 \cdot 0$ \\
\hline Death certificates not obtained & 3 & - & 0 & - \\
\hline
\end{tabular}

*Expected deaths based on US white male mortality rates.

\section{Results}

Because of limited industrial hygiene data, length of employment on the jobs of highest concern (still and reactor operators in both units, and foreman and lead burners in unit 1) was the only indicator of exposure used in the analysis. Table 4 shows duration of exposure, by year first exposed, for each manufacturing unit. Several of the men, especially in unit 2, may have held other jobs, resulting in potential low intensity EDB exposure, which would not have been included in the tabulation.

Table 5 summarises observed and expected deaths, by cause, for the two production units excluding the five employees from unit 2 who had worked with arsenicals in addition to EDB. Three deaths have occurred among these five people, compared with $0 \cdot 6$ expected. Two of the deaths were due to respiratory cancer. One death from respiratory cancer has been reported to date among individuals exposed only to EDB. Information on cause of death has not been obtained for three of the 21 deaths in unit 1 . One of these individuals died within two years of being drafted into the armed Forces and may therefore have been killed in military action. In unit 1 one person with 26 months of exposure, and whose immediate cause of death was listed as arteriosclerotic heart disease, had a metastatic carcinoma of the lymph nodes listed under other significant conditions at death (primary site undetermined).

Increased malignancy and respiratory deaths were

Table 6 Observed and expected deaths for selected causes by duration of exposure and interval since first exposure, unit 1 and unit 2 less arsenicals employees, 1940-75

\begin{tabular}{|c|c|c|c|c|}
\hline \multirow{2}{*}{$\begin{array}{l}\text { Duration of exposure and interval since first } \\
\text { exposure }\end{array}$} & \multicolumn{2}{|c|}{ Total deaths } & \multicolumn{2}{|c|}{ Total malignancies } \\
\hline & Observed & Expected & Observed & Expected \\
\hline \multicolumn{5}{|c|}{$<$ I year exposure } \\
\hline$<15$ years since first exposure & 0 & 1.7 & 0 & $0 \cdot 2$ \\
\hline 15-24 years since first exposure & 2 & 1.6 & 0 & $0 \cdot 3$ \\
\hline$\geqslant 25$ years since first exposure & 0 & 0.9 & 0 & $0 \cdot 2$ \\
\hline Total & 2 & $4 \cdot 2^{*}$ & 0 & 0.7 \\
\hline \multicolumn{5}{|c|}{ 1-5 years' exposure } \\
\hline$<15$ years since first exposure & 8 & $7 \cdot 1$ & 1 & 1.0 \\
\hline $15-24$ years since first exposure & 10 & $7 \cdot 2$ & 1 & $1 \cdot 2$ \\
\hline$\geqslant 25$ years since first exposure & 5 & $5 \cdot 4$ & 1 & $1 \cdot 2$ \\
\hline Total & 23 & $19 \cdot 8$ & 3 & $3 \cdot \overline{5}$ \\
\hline \multicolumn{5}{|c|}{$\geqslant 6$ years' exposure } \\
\hline$<15$ years since first exposure & 2 & $1 \cdot 9$ & 0 & $0 \cdot 3$ \\
\hline $15-24$ years since first exposure & 6 & $3 \cdot 5$ & 3 & 0.7 \\
\hline$\geqslant 25$ years since first exposure & 3 & $3 \cdot 2$ & 1 & 0.7 \\
\hline \multicolumn{5}{|c|}{ Total years' exposure } \\
\hline$<15$ years since first exposure & 10 & $10 \cdot 7$ & 1 & $1 \cdot 5$ \\
\hline 15-24 years since first exposure & 18 & $12 \cdot 3$ & 4 & $2 \cdot 2$ \\
\hline$\geqslant 25$ years since first exposure & 8 & $9 \cdot 5$ & 2 & $2 \cdot 1$ \\
\hline Total & 36 & $32 \cdot 5$ & 7 & $5 \cdot 8$ \\
\hline
\end{tabular}

* Expected number of deaths not additive due to rounding errors. 
Table 7 Case summaries of eight employees whose deaths were due to malignant neoplasms

\begin{tabular}{|c|c|c|c|c|c|c|c|c|}
\hline $\begin{array}{l}\text { Case } \\
\text { No }\end{array}$ & $\begin{array}{l}\text { Date of Ist exposure to EDB, duration } \\
\text { of exposure, and position held }\end{array}$ & $\begin{array}{l}\text { Year of } \\
\text { death }\end{array}$ & $\begin{array}{l}\text { Age at } \\
\text { death }\end{array}$ & $\begin{array}{l}\text { Primary site of } \\
\text { malignancy }\end{array}$ & Necropsy & $\begin{array}{l}\text { Family } \\
\text { cancer } \\
\text { history }\end{array}$ & $\begin{array}{l}\text { Smoking } \\
\text { history }\end{array}$ & $\begin{array}{l}\text { Other significant } \\
\text { exposure }\end{array}$ \\
\hline 1 & $1933 ; 102$ months, operator & 1942 & 58 & Lung & No & Not known & Not known & $\begin{array}{l}\text { Arsenicals } 1 \frac{1}{2} \\
\text { months }\end{array}$ \\
\hline 2 & $1938 ; 111$ months, operator & 1952 & 47 & Lung & No & Not known & Not known & $\begin{array}{l}\text { Arsenicals } 20 \\
\text { months }\end{array}$ \\
\hline $3 *$ & $1929 ; 136$ months, operator & 1950 & 70 & Stomach & No & Son & Not known & 一 \\
\hline $4^{*}$ & $1948 ; 48$ months, operator & 1970 & 55 & Stomach & No & $\begin{array}{l}\text { Mother } \\
\text { Father }\end{array}$ & $\begin{array}{l}\geqslant 1 \mathrm{pk} / \text { day } \\
\geqslant 25 \mathrm{yr}\end{array}$ & 一 \\
\hline 5 & $1937 ; 19$ months, operator & 1962 & 88 & Prostate & No & Not known & Not known & - \\
\hline 6 & $1949 ; 79$ months, operator & 1969 & 51 & $\begin{array}{l}\text { Reticulum-cell } \\
\text { sarcoma }\end{array}$ & No & None & Not known & 一 \\
\hline 7 & $1952 ; 46$ months, operator & 1963 & 63 & Site unknown & No & None & Not known & - \\
\hline 8 & $1943 ; 224$ months, foreman and operator & 1966 & 59 & Pancreas & Yes & Not known & Not known & - \\
\hline 9 & $1944 ; 242$ months, foreman and operator & 1974 & 68 & Lung & $?$ & Not known & Not known & - \\
\hline
\end{tabular}

*Cases 3 and 4 were father and son.

observed among employees in unit 2 (total malignant neoplasms: 5 versus $2 \cdot 2$ expected, $\mathrm{p}<0.072$; malignant neoplasms of the digestive system: 2 versus 0.7 expected, $\mathrm{p}<0.156$; all other malignant neoplasms: 3 versus 0.9 expected, $p<0.063$; and influenza and pneumonia: 2 versus 0.3 expected, $\mathrm{p}<0.037$ ). The levels of significance (one-tailed test) were estimated assuming a Poisson distribution.

In table 6 mortality was examined in relation to duration of exposure and interval since first exposure for both units combined. No statistically significant increase in deaths relative to duration of exposure was observed.

Table 7 summarises pertinent findings for the nine cases in which the underlying cause of death was a malignant neoplasm. The lack of completeness in the information is readily apparent. A necropsy was performed in only one of the cases, and smoking history was known for only one person. Occupational exposure to arsenic-containing compounds was determined for two of the cases. A third individual was treated topically with Fowler's solution (which contains potassium arsenite) for a chronic dermatological problem 25 years before he died from a reticulum-cell sarcoma. Interestingly the two individuals who died from stomach cancer were father and son.

\section{Discussion}

The findings of this observational study need to be interpreted cautiously owing to the limitations in the size of the study population and the variety of toxic agents to which individuals in unit 2 may have been exposed. The three deaths from diseases of the respiratory system (1.3 expected) occurred among unit 2 employees. None of these individuals worked in an
EDB area at the time of death. One of the men, who died at the age of 68 from aspiration pneumonia, had worked for 12 months in EDB production and for 15 years in other areas of organic bromide production. Other conditions at death were diabetes mellitus and congestive heart failure. A second person worked for 14 years in the ethylene dibromide department, primarily in ethylene production, with one year as a still or reactor operator. He died in 1949 at the age of 67 from pneumonia. Other conditions included coronary insufficiency and a questionable cancer of the stomach. The third individual died from pulmonary emphysema at the age of 67, 20 years after one year of exposure to EDB. There is no apparent connection between these deaths and exposure to EDB.

There were fewer deaths than expected from malignant neoplasms ( 2 versus 3.6 expected) in the manufacturing unit that produced only EDB (unit 1), whereas five versus $2 \cdot 2$ expected deaths from malignant neoplasms were observed among the individuals in unit 2 without exposure to arsenicals. Although not statistically significant, there is an increase in cancer mortality among employees with more than six years' exposure to EDB (table 6). Among the four observed malignant neoplasms in this subcohort, however, no two were of the same site. In an assessment of carcinogenic risk Ramsey et $a l^{7}$ showed that a model derived from the animal findings of Olson et al ${ }^{1}$ predicted far more deaths from malignancy than have been observed in the present employee population, thereby demonstrating the difficulty of direct extrapolation from animal to human experience.

The findings of this investigation indicate a need for (a) continued surveillance of this cohort of 161 employees, and $(b)$ an industry-wide study of mortality among employees in EDB manufacturing. 


\section{References}

1 Olson WA, Habermann RT, Weisburger EK, Ward JM, Weisburger $\mathrm{JH}$. Induction of stomach cancer in rats and mice by halogenated aliphatic fumigants. J Natl Cancer Inst 1973;51:1993-5.

2 Plotnick HB. Carcinogenesis in rats of combined ethylene bromide and disulfiram. JAMA 1978;239:1609.

${ }^{3}$ National Institute for Occupational Safety and Health. Study of carcinogenicity and toxicity of inhaled 1,2dibromoethane in rats treated with disulfiram. Department of Health, Education and Welfare, Contract No 210-760131. 1979, report in preparation.

4 kowe VK, Spencer HC, McCollister DD, Hollingsworth MS, Adams EM. Toxicity of ethylene dibromide deter- mined on experimental animals. Arch Ind Hygiene Occup Med 1952;6:158-73.

${ }^{5}$ Bondi A, Alumot E. Effect of ethylene dibromide fumigated feed on animals. Final report of research conducted under grant authorised by US Public Law 480 . Submitted by Faculty of Agriculture, Hebrew University, Rehovot, Israel. Project No A10 SMD-4(a), grant No FC-15-117, report period: August 1961-August $1966.81 \mathrm{pp}$, plus appendix. 5th annual report SVI pp.

${ }^{6}$ Ott MG, Holder BB, Gordon HL. Respiratory cancer and occupational exposure to arsenicals. Arch Environ Health 1974;29:250-5.

7 Ramsey JC, Park CN, Ott MG, Gehring PJ. Carcinogenic risk assessment: ethylene dibromide. Toxicol Applied Pharmacol 1978;47:411-4. 